\title{
Russia - Post-Soviet Central Asia Cooperation in Information and Media
}

\author{
Ksenia Gennadiyevna Muratshina ${ }^{1}$, \\ Marina Vladimirovna Valeeva ${ }^{2}$ \\ ${ }^{1}$ Ural Federal University, Ekaterinburg, Russia \\ ${ }^{2}$ Ural Federal University, Ekaterinburg, Russia \\ Corresponding author: Ksenia Gennadiyevna Muratshina, \\ ksenia.muratshina@urfu.ru
}

\begin{abstract}
The authors discuss the cooperation between Russia and each of the post-Soviet Central Asian states (Kazakhstan, Kyrgyzstan, Uzbekistan, Tajikistan, Turkmenistan) in information and media. The regulatory frameworks for bilateral cooperation are studied, and their practical implementation is also reviewed. The analysis is based on the study of the documents and events of the last decade.

Keywords: Russia, Central Asia, Kazakhstan, Kyrgyzstan, Tajikistan, Uzbekistan, Turkmenistan, people-to-people exchanges, information, media
\end{abstract}

\section{Introduction}

The cooperation between Russia and the countries of Central Asia (the Republic of Kazakhstan, the Republic of Tajikistan, the Kyrgyz Republic, the Republic of Uzbekistan, and Turkmenistan) at present stage is an example of intensive partnership and friendly ties in the post-Soviet space [Lavrov, 2017; Ministry of Foreign Affairs of the Russian Federation, 2019]. In this partnership, the examples of cooperation in military, political and economic areas are well-researched in academic community. At the same time, the development of what is usually addressed in post-Soviet research as humanitarian cooperation, namely the relations in the areas of culture, education, tourism, sport, information and media, and youth policy, has been less studied so far. Meanwhile, humanitarian cooperation has already become one of the key components of inter-state relations, as a means of people-to-people exchanges.

We analyze the way the humanitarian cooperation between Russia and post-Soviet Central Asian countries is carried out in such area as informa- 
tion and media, which includes broadcasting, contacts of the national media communities, joint projects and special events [CIS, 2005].

\section{Researched material}

We consequently study the regulatory framework, which has been created for the cooperation between Russia and its Central-Asian partners on the bilateral basis, and the practical steps in cooperation, which have been made in bilateral ties so far. Information and media, as a crucially important area of social and political life, can be regarded as a channel of intercultural dialogue and a strategic component of national information security. The development of international cooperation in information and media can be considered an indicator of maturity and mutual trust in interstate relations.

The analysis of information and media cooperation between Russia and post-Soviet Central Asia is a curious topic of a high academic interest, due to a wide range of contradictory factors, which specifically shape its development in modern conditions. Information space in the countries of Central Asia has some special common characteristics: on the one hand, it is strictly controlled by the states, with the ideological use of mass media by the governments, as well as with the wide distribution of national information products, aimed at strengthening national identity [Rollberg and Laruelle, 2015; Junisbai et al., 2015; Anceschi, 2015; Shafiev and Miles, 2015; Rollberg, 2015]. On the other hand, this control cannot exclude the advance of foreign players in Central Asian media space, and cannot weaken the interest of the consumers of information towards the external sources [Rollberg and Laruelle, 2015; 9-10]. Besides, researchers note that the media markets of Central Asia have not expanded enough to have large independent media production [Rollberg, 2015]. For example, entertainment programs from Russia often attract large audience, and few local news programs, concerts and TV series compete with the popularity of Russian products [Laruelle, 2015].

Another factor is the dissemination of the Russian language in Central Asia. In three out of five Central Asian countries (Kazakhstan, Kyrgyzstan and Tajikistan), the Russian language has an official status of the second used language in the country (in Kazakhstan and Kyrgyzstan - official, in Tajikistan - the language of international communication), while in Uzbekistan and Turkmenistan it has no special status by law. Moreover, according to some estimations, the percentage of local citizens who do not speak Russian, has reached $50 \%$ in each of post-Soviet Central Asian countries [Bekmurzaev, 
2019]. Therefore, the positive factors for developing humanitarian cooperation here are adjacent to the negative ones.

Yet there is one more factor that potentially promotes media contacts as much as the Russian language dissemination, - the Russian expatriate communities. In Kazakhstan, the number of Russian community reaches 3.5 million people, in Uzbekistan - 650 thousand, in Kyrgyzstan - 364.5 thousand, in Tajikistan -34.8 thousand. Absolute data for Turkmenistan are unavailable in open statistics and scientific literature, but there is evidence of small Russian communities still living there [Sukharevskaya, 2019].

Thus, the conditions in which Russia - Central Asia media cooperation is carried out, are rather special, and the more interesting the research of their organisation appears to be.

\section{Research methodology}

The research methodology we use is a combination of two methodological approaches. The first one is the discourse analysis, applied with the purpose to study and compare the texts of the bilateral diplomatic documents. The second one is the institutional approach that includes outlining the participants and the arrangements of bilateral cooperation between Russia and each of the Central Asian countries.

\section{Research description}

We have studied information and media cooperation between Russia and each of the Central Asian countries - Kazakhstan, Kyrgyzstan, Tajikistan, Uzbekistan, Turkmenistan. The sources used include the diplomatic documents, which regulate the bilateral cooperation, the press-releases and the reports of governmental and non-governmental organizations, and the media newsletters.

\section{Research results}

\subsection{Russia and Kazakhstan}

Information and media cooperation between Russia and Kazakhstan is carried out within the framework of the following documents: the Agreement on the cooperation in the areas of culture, science and education, 1994 [Electronic fund of legal and technical documentation, 1994], the Agreement on the procedure and the conditions of distribution of the programs of the Russian television and radio broadcasting organizations in Kazakhstan, and 
the programs of the Kazakh television and radio broadcasting organization in Russia, 1996 [Electronic fund of legal and technical documentation, 1996], the Agreement on the cooperation in the area of information, 1998 [Electronic fund of legal and technical documentation, 1998] and the Agreement on the status of mass media reporters from Russia in Kazakhstan and vice versa, 2000 [Ministry of Foreign Affairs of the Russian Federation, 2000]. All these documents are rather detailed, and the rights and obligations of the parties are mutual and symmetrical. The countries committed themselves to developing the cooperation in the exchange of information between agencies and editors of their mass media, the mutual distribution of their mass media products, the contacts of information agencies and other organizations operating in the field of information, the mutual assistance to TV and radio broadcasting and to accredited mass media representatives, the training of experts in media, and the exchange of statistics and experience in the sphere of legal regulation of mass media.

Concerning radio broadcasting, we can witness that in 2017, the following Russian stations were broadcast in Kazakhstan: "Avtoradio", "Russkoye radio", "Retro FM", "Love Radio", "Europe plus", "Dorozhnoye radio" [Federal Agency for Press and Mass Media, 2018, 37-38]. In 2018, "Avtoradio" was removed, while "Hit FM" and "Radio Dacha" were added [Federal Agency for Press and Mass Media, 2019, 43-44]. Russian TV channels in Kazakhstan are available on cable and satellite TV. During the last decade, there had been difficulties from time to time with their broadcasting, but everything was settled by means of negotiations. In 2012, the press-service of the cable TV operator "Alma TV" announced that the company had stopped broadcasting Russian channels "RTR Planet", "Russia 24" and "Russia-Culture" because of the impossibility to find compromise on the cooperation conditions [Vesti, 2012], but later the issue was settled, and the broadcasting continued. In 2017, a similar situation happened when the operators "Kazakhtelecom" and "Alma TV" announced a suspension of broadcasting of four Russian channels - "NTV-Mir", "RTR-Planet", "Russia-24" and "Russia-Culture" due to the reason of a requirement from the right holder to increase the payment for broadcasting, but later this issue was settled, too [Forbes, 2017]. Kazakh channel "KazakhTV" started broadcasting in Russia in 2019 [Federal Agency for Press and Mass Media, 2020, 60].

People-to-people exchanges in Russia-Kazakhstan media cooperation are also vibrant. In 2014, the Deputy Minister of communications and mass 
media of Russia and Vice Minister on investments and development of Kazakhstan met in Moscow and discussed in detail the cooperation in media. They agreed to maintain regular contacts in order to discuss the development of media markets of the two countries, as well as the development of media literacy. Russia agreed to share its practice in this area with Kazakhstan [Ministry of Digital Development, 2014].

In 2015, a delegation from Russia participated in the conference "Legal regulation of limits of freedom of speech" in Astana [Commonwealth of Eurasian nations, 2015]. In 2016, the Minister of communication and mass media of the Russian Federation and the Minister of information and communications of the Republic of Kazakhstan held a meeting in order to discuss the enlargement of cooperation in information, including combating the use of Internet by criminals (especially in social networks), as well as the changes in legislation of the countries, regulating the issues of information. At the same time, the representatives of Kazakhstan denied Russia's idea of the withdrawal of limits for the TV channels of both countries on their work at the advertising market and on the limits of foreign ownership. Later in 2016, the Russian Ministry of communication and mass media held a video conference for the representatives of Russian TV companies and Kazakh TV operators. As a result, the parties agreed to remove advertising from Russian TV content and increase its price by one third [Ministry of Digital Development, 2018]. In 2018, Kazakh developers of software for mobile phones were granted a right to use the standard for mobile applications developed by the "Russian system of quality" (Roskachestvo) [Russian periodical press, $2019,100]$.

In 2016 [Ural-Eurasia, 2016] and 2018 [Ural-Eurasia, 2018] Kazakh journalists participated in educational training in Yekaterinburg, and in 2019 in Moscow [Sputnik News, 2019]. In 2018, Russia and Kazakhstan jointly organized a summer training for reporters in Astana (journalists from Russia, Kazakhstan, Kyrgyzstan and Uzbekistan took part in it) [Ural-Eurasia, 2018]; in 2018, representatives of Kazakhstan participated in the conference "Radio in global media competition" held by the Russian Academy of Radio in Moscow [Federal Agency for Press, 2019, 5]. In 2019, a large press-tour was organized for Kazakh reporters in Moscow [Embassy of the Republic of Kazakhstan in the Russian Federation, 2019]. Moreover, in 2019, Kazakhstan was one of the hosts of the "Digital dictation", launched by Russia. The event was organized in Belarus as well. The dictation was held in specially selected 
centers, accessible for everyone, and included questions on digital literacy. The aim of this event was to increase the public digital literacy [Federal Agency for Press and Mass Media, 2020, 22].

\subsection{Russia and Kyrgyzstan}

Russian-Kyrgyz ties in information and media are regulated by the following set of documents: the Agreement on the humanitarian cooperation, 2012 [Electronic fund of legal and technical documentation, 2012], the Agreement on the status of mass media reporters, 1995 [Russian Embassy in Kyrgyzstan, 1995], the Agreement on the procedure and the conditions of distribution of the programs of the Russian television and radio broadcasting organizations in Kyrgyzstan, 1996 [Conventions.ru, 1996] and the Agreement on the cooperation in the area of information, 2000 [Electronic fund of legal and technical documentation, 1999]. Notably, the composition and the contents of the documents are almost similar to those between Russia and Kazakhstan, except for one difference: while Russian-Kazakh document on broadcasting has mutual force, Russian-Kyrgyz agreement concerns only the distribution of Russian programs in Kyrgyzstan. Perhaps, this can be explained by the difference in geographical position: Russia and Kazakhstan are the nearest neighbors with the longest border, providing better conditions for technical interaction.

In broadcasting, the following Russian stations were broadcast in Kyrgyzstan in 2017 - "Avtoradio", "Retro FM", "Mir", "Europe plus", "Dorozhnoye radio", "Hit FM", "Radio Record" and "Sputnik" [Radio-broadcasting in Russia, 2018, 37-38]. In 2018, "Hit FM" was removed [Radio broadcasting in Russia, 2019, 43-44], but in 2019 it was returned. At the same time, "Dorozhnoye radio" was removed in 2019 [Radio in Russia, 2019, 51]. The social digital TV multiplex in Kyrgyzstan includes the following Russian channels: "First channel. World network" and "RTR Planet" [Ministry of Digital Development, 2019]. Other channels are available on the platforms of cable and satellite TV. According to the data of the Ministry of culture of Kyrgyzstan, Russian TV channels have high ratings, therefore their broadcasting is regularly prolonged despite the fact that there are opponents to this prolongation, considering it a strong competition to Kyrgyz media production [Krasnaya vesna, 2020; Russian newspaper, 2015].

The level of people-to-people contacts in Russian-Kyrgyz cooperation is also quite high at the present stage. In 2014, in Bishkek the experts from Moscow State Linguistic University held a training "Russian-speaking journalism: current state and development trends" for more than 50 Kyrgyz participants 
from the country's leading media - newspapers "Vecheryi Bichkek", "Argumenty i Fakty - Kyrgyzstan", "Chuiskie Izvestia", information agencies "24, kg", "Vesti.kg", "Russia in Kyrgyzstan", the journal "Delovoi sobesednik" and TV channel " $5^{\text {th }}$ channel". The issues discussed included the specific features of content in quality journalism, the ways and the forms of news presentation in printed and electronic mass media [Soloviov, 2016].

In 2015, the Deputy Minister of communication and mass media of the Russian Federation and the Minister of culture, information and tourism of the Kyrgyz Republic agreed on the exchange of experience in the area of creating digital TV infrastructure [Ministry of Digital Development, 2015]. In 2016 the Deputy Minister of communication and mass media of RF and Chairman of Government Committee of informational technologies and communication of KR agreed on widening cooperation between mail agencies and operators of the two countries [Ministry of Digital Development, 2018]. In 2018, Kyrgyz developers of software for mobile phones were granted a right to use the standard for mobile applications, developed by the "Russian system of quality" (Roskachestvo) [Russian periodical press, 2019, 100]. In 2016 [Ural-Eurasia, 2016] and 2018 [Ural-Eurasia, 2018] Kyrgyz journalists attended the educational trainings for reporters in Yekaterinburg and the Russian-Kazakh training school in Astana [Ural-Eurasia, 2018], in 2019 the training in Moscow [Sputnik News, 2019]. In 2018 the representatives from Kyrgyzstan participated in the conference "Radio in global media competition" held by the Russian Academy of Radio in Moscow [Federal Agency for Press and Mass Media, 2019, 5].

\subsection{Russia and Tajikistan}

The ties between Russia and Tajikistan in information and media are regulated by the following set of documents: the Agreement on the cooperation in the areas of culture, science and education, 1995 [Electronic fund of legal and technical documentation, 1995], the Agreement on the cooperation in the area of information, 2004 [Electronic fund of legal and technical documentation, 2004], the Agreement on the status of mass media reporters, 2001 [Electronic fund of legal and technical documentation, 2001] and the Agreement on the procedure and conditions of distribution of the programs of the Russian television and radio broadcasting organizations in the territory of the Republic of Tajikistan, 1999 [Electronic fund of legal and technical documentation, 1999]. The types and the contents of these agreements are similar to those between Russia and Kyrgyzstan. 
According to the data of Russian Federal Agency on press and mass communications, in 2017 only one Russian radio station was broadcast in Tajikistan - "Love Radio" [Federal Agency for Press and Mass Media, 2018, 37]. In 2019 "Novoye radio" was added to it. But the number of broadcasting points is very low - one for each, i. e. the coverage area of both stations is minimal [Federal Agency for Press and Mass Media, 2020, 50]. Russian TV channels in Tajikistan are available on cable and satellite TV. In Russia, it was reported that Tajik TV channel "Jahonnamo" [Commonwealth of Eurasian nations, 2017] is available in Russia via cable and satellite systems, meanwhile migrants from Tajikistan, living in Russia and interviewed by K. Muratshina, noted that they watch Tajik TV on Internet.

The results of an opinion survey by Tajik agency "Media consulting" on the topic "Media preferences of citizens of the Republic of Tajikistan: TV, radio, press, web-sites, social networks and messengers" conducted in 2019, suggest that Russian TV channels are the most popular in Tajikistan among foreign TV channels, and the TV channel "Russia" is ranked as the most viewed. In addition, such Russian channels as "NTV", "ORT", "RTR-Planet", "TNT", "Zvezda", were also noted by the respondents [Zerkalo, 2020].

The contacts of Russian and Tajik media communities, people-to-people exchanges have also occurred in the recent decade. In 2016 [Ural-Eurasia, 2016] and 2018 [Ural-Eurasia, 2018] Tajik journalists participated in educational training for reporters in Yekaterinburg, in 2019 — in Moscow [Sputnik News, 2019]. In addition, in 2018 Tajik representatives took part in the conference "Radio in global media competition" held by the Russian Academy of Radio in Moscow as well as in the international Forum of Russian-language broadcasters "Russian-language broadcasting in the conditions of global increase of the role of information" [Federal Agency for Press and Mass Media, 2019, 5]. Similarly, Tajikistan was represented at this Forum in 2019. [Federal Agency for Press and Mass Media, 2020, 5].

\subsection{Russia and Uzbekistan}

Information and media ties between Russia and Uzbekistan are carried out within the framework of the bilateral documents: the Agreement on the cooperation in the areas of culture, science and technology, education, healthcare, information, sport and tourism, 1993 [Electronic fund of legal and technical documentation, 1993], the Agreement on the status of mass media reporters, 1998 [Electronic fund of legal and technical documentation, 1998], and the Agreement on the cooperation in the area of information, 
1999 [Electronic fund of legal and technical documentation, 1999]. These documents are almost similar to Russia's documents with Kyrgyzstan and Tajikistan, however, Russia and Uzbekistan do not have a document on the broadcasting of TV and radio stations. As a result, according to the 2019 data, no Russian radio stations were broadcast in Uzbekistan [Federal Agency for Press and Mass Media, 2020, 50-51]. Russian TV channels are available in Uzbekistan via cable and satellite TV, and they have always been extremely popular [Koshkin, 2003], bur several conflicts occurred throughout the last decade. In 2010, "Kamalak" - one of the large Uzbek cable operators broadcasting Russian channels - terminated its activity. Moreover, Russian channels "TNT" and "DTV" were excluded from Uzbek cable TV network. This resulted in huge demand for satellite aerials in Uzbekistan [Fergana, 2011]. In 2011, a group of Uzbek experts in culture and art published an open letter addressed to the management of TV channel "Russia" and condemned the documentary "Without Russia", that had been dedicated to the violation of human rights of Russian expatriates in Central Asia. In 2013, Uzbek company "UzDigital-TV" terminated broadcasting of Russian TV channel "Domashnyi", and earlier Uzbek side had also stopped the broadcasting of Russian channels "TVC", "Ren-TV" and others. The reason was the discontent of the Uzbek side, as it was declared that the content of those channels did not match Uzbek traditional vision of morality [Fergana, 2013]. At present, Russian TV channels are available in Uzbekistan only via satellite TV. As for the reception of Uzbek TV channels in Russia, Uzbek migrants told K. Muratshina that they watch Uzbek TV in the Internet, as the quality of its reception via satellite TV is poor.

As for the contacts of professional communities, there are regular meetings of Russian and Uzbek ministerial representatives, with the purpose of exchange of experience [Ministry of Digital Development, 2018; Ministry of Digital Development, 2019]. In 2018, Uzbek journalists participated in educational training in Yekaterinburg [Ural-Eurasia, 2018], in Russian-Kazakh training for reporters in Astana [Ural-Eurasia, 2018], in the conference "Radio in global media competition" in Moscow, and in the international Forum of Russian-language broadcasters [Federal Agency for Press and Mass Media, 2019, 5]. The first Russian and Uzbek Media Forum was held in 2018, it was organized by the National TV and Radio Company of Uzbekistan and the Ministry of digital development, communication and mass media of the Russian Federation. Issues important for Russian, Uzbek and international 
mass media were discussed at the forum, and it was beneficial for direct contacts between representatives of the professional communities of both countries [Sputnik Tajikistan, 2018]. In 2019, representatives of Uzbekistan participated again in Moscow International Forum of Russian-language broadcasters [Federal Agency for Press and Mass Media, 2020, 5].

\subsection{Russia and Turkmenistan}

The cooperation of Russia and Turkmenistan in the area of information is minimal due to the specific political course of the Central Asian country, that from the moment of announcement of its continuous neutrality in 1995 [Electronic fund of legal and technical documentation, 1995] follows the way of formation of a closed society. There are no specialized agreements on cooperation in the area of information between these two countries, except for the Agreement on the status of mass media reporters, 1995 [Conventions.ru, 1995].

Russian TV channels (especially "Pervyi" channel, Russia, as well as entertainment channels, for example: “TNT", "STS”, etc.) are available for Turkmen citizens on satellite TV and are quite popular among those who can afford buying an aerial [CABAR.asia, 2019].

Although the Treaty between Russia and Turkmenistan on strategic partnership, signed in 2017, binds the countries, inter alia, "to support the development of cooperation between informational services (agencies)" and "to assist to the training courses for the staff engaged of the mass media" [Electronic fund for legal and technical documentation, 2017], regular direct contacts of Russian and Turkmen media communities have not been formed, due to Turkmenistan's policy of maximum closure of its social life and information space from the rest of the world.

\section{Conclusion}

The results of the analysis of Russia's bilateral cooperation in information and media with the post-soviet Central Asian countries have brought the research to the following conclusions.

Each of the Central Asian countries, except for Turkmenistan, has specialized agreements with Russia on cooperation in information and media, which are usually standard for the partner countries in terms of the set of mutual obligations. The agreements are directed at the simplification and the clear regulation of the cooperation, ensuring the work of mass media agencies and reporters on a mutual basis, the accessibility of TV channels 
broadcasting, and the contacts of professional media communities. Talking about the institutional structure of cooperation, we can indicate that it usually includes the ministerial level, the allowance of TV and radio broadcasting, and the contacts of non-governmental organizations, namely the professional communities.

Practical implementation of agreements is also of a similar nature. The state parties organize regular communication between their specialized ministries with the purpose of exchange of experience and planning the cooperation, hold meetings, participate in joint education projects and forums. Certainly, in order to continue these ties, both the resolution of the governments and the development of the direct contacts network are vitally needed.

The most intensive practical contacts in information and media are those of Russia with Kazakhstan, Kyrgyzstan and Tajikistan. Remarkably, the role of the official status of Russian language in these countries is a meaningful factor of the coverage of the continuous communication and exchanges. Paradoxically, in Uzbekistan and Turkmenistan, where Russian language has no special status, the institutional structure of exchanges is incomplete, but at the same time, Russian media still remain popular. This situation illustrates the constant demand among the population for the continuation and expansion of information exchanges. However, the arrangements of ties of governmental institutions and professional communities in the case of Turkmenistan are not used at all, and in the case of Uzbekistan, are used less than with the rest of Central Asia.

It seems that for Russia, a promising area of cooperation development can be new TV and radio programs or channels, focused on Central Asian audience, that would be similar to those already existing (for example, international CIS TV and radio company "Mir", or "Sputnik" agency, that produces news and radio programs in various languages), but will also take into account the local cultural specifics and requirements to the content.

Furthermore, the results of the research indicate that the common information space of post-Soviet countries still exists, and its maintenance will be essential for the development of integration and mutual understanding between nations. However, this development requires continuous and intensive work of all the cooperation parties.

\section{Conflict of Interest}

The authors have no conflict of interest to declare. 


\section{Acknowledgement}

The research was supported by the Russian Science Foundation, grant No. 19-78-10060.

\section{References:}

1. S. Lavrov. Partnerstvo, ispytannoye vremya [Partnership tested by time]. Rossiyskaya Gazeta, (2017) https://rg.ru/2017/10/04/lavrov-pomoshch-rf-centralnojazii-prevysila-6-milliardov-dollarov.html (Accessed 1.04.2020).

2. Rossiya i Tsentral'naya Aziya. Ministerstvo inostrannykh del Rossiyskoy Federatsii [Russia and Central Asia. Ministry of Foreign Affairs of the Russian Federation], (2019) https://www.mid.ru/rossia-i-problemy-central-noj-azii (Accessed 13.04.2020).

3. Soglasheniye o gumanitarnom sotrudnichestve gosudarstv-uchastnikov SNG. Mezhgosudarstvennyy Fond gumanitarnogo sotrudnichestva gosudarstvuchastnikov. [Agreement on the Humanitarian Cooperation of the CIS Member States. The Intergovernmental Foundation for Educational, Scientific and Cultural Cooperation of the CIS], (2005). http://mfgs-sng.org/sgs/gum_sotr/ (Accessed 26.08.2020).

4. P. Rollberg, M. Laruelle. The Media Landscape in Central Asia: Introduction to the Special Issue. Demokratizatsiya: The Journal of Post-Soviet Democratization. Vol. 2, No 3 (2015), Pp. 227-232.

5. B. Junisbai, A. Junisbai, N. Y. Fry. Mass Media Consumption in Post-Soviet Kyrgyzstan and Kazakhstan: The View from Below. Demokratizatsiya: The Journal of Post-Soviet Democratization. Vol. 23, No 3 (2015), Pp. 233-256.

6. L. Anceschi. The Persistence of Media Control Under Consolidated Authoritarianism: Containing Kazakhstan's Digital Media. Demokratizatsiya: The Journal of Post-Soviet Democratization. Vol. 23, No 3 (2015), Pp. 277-295.

7. A. Shafiev, M. Miles. Friends, Foes, and Facebook: Blocking the Internet in Tajikistan. Demokratizatsiya: The Journal of Post-Soviet Democratization. Vol. 23, No 3 (2015), Pp. 297-319.

8. P. Rollberg. Small Screen Nation Building: Astana - My Love. Demokratizatsiya: The Journal of Post-Soviet Democratization. Vol. 23, No 3 (2015), Pp. 341-358.

9. M. Laruelle. In Search of Kazakhness: The Televisual Landscape and Screening of Nation in Kazakhstan. Demokratizatsiya: The Journal of Post-Soviet Democratization. Vol. 23, No 3 (2015), Pp. 321-340. 
10. N. Bekmurzaev. Polozheniye russkogo yazyka v stranakh Tsentral'noy Azii. [The position of Russian language in Central Asian countries]. Central Asian Bureau for Analytical Reporting CABAR.asia, (2019) https://cabar.asia/ru/polozhenierusskogo-yazyka-v-stranah-tsentralnoj-azii/\#_ftn9 (Accessed 15.04.2020).

11. O. Sukharevskaya. Russkiye v Tsentral'noy Azii: problemy i perspektivy. Informatsionno-analiticheskiy tsentr. Laboratoriya obshchestvenno-politicheskogo razvitiya stran blizhnego zarubezhya. [Russians in Central Asia: problems and perspectives. Centre for Information and Analysis], (2019) https://ia-centr.ru/experts/ olga-sukharevskaya/russkie-v-tsentralnoy-azii-problemy-i-perspektivy/ (Accessed 13.04.2020).

12. Soglasheniye mezhdu Pravitel'stvom Rossiyskoy Federatsii i Pravitel'stvom Respubliki Kazakhstan o sotrudnichestve v oblasti kul'tury, nauki i obrazovaniya. Elektronnyy fond pravovoy i normativno-tekhnicheskoy dokumentatsii. [Agreement between the Government of the Russian Federation and the Government of the Republic of Kazakhstan on the cooperation in the areas of culture, science and education. Electronic fund of legal and technical documentation], (1994). http:// docs.cntd.ru/document/901730135 (Accessed 14.04.2020).

13. Soglasheniye mezhdu Pravitel'stvom Rossiyskoy Federatsii i Pravitel'stvom Respubliki Kazakhstan o poryadke i usloviyakh rasprostraneniya programm rossiyskikh teleradioveshchatel'nykh organizatsiy na territorii Respubliki Kazakhstan i teleradioveshchatel'nykh programm kazakhstanskoy teleradioorganizatsii na territorii Rossiyskoy Federatsii. Elektronnyy fond pravovoy i normativno-tekhnicheskoy dokumentatsii. [Agreement between the Government of the Russian Federation and the Government of the Republic of Kazakhstan on the procedure and the conditions of the distribution of the programs of the Russian television and radio broadcasting organizations in the territory of the Republic of Kazakhstan, and the programs of the Kazakh television and radio broadcasting organization in the territory of the Russian Federation. Electronic fund of legal and technical documentation], (1996). http://docs.cntd.ru/document/1902295 (Accessed 14.04.2020).

14. Soglasheniye mezhdu Pravitel'stvom Rossiyskoy Federatsii i Pravitel'stvom Respubliki Kazakhstan o sotrudnichestve v oblasti informatsii. Elektronnyy fond pravovoy i normativno-tekhnicheskoy dokumentatsii. [Agreement between the Government of the Russian Federation and the Government of the Republic of Kazakhstan on the cooperation in the area of information. Electronic fund of legal and technical documentation], (1998). http://docs.cntd.ru/document/901750941 (Accessed 14.04.2020). 
15. Soglasheniye mezhdu Pravitel'stvom Rossiyskoy Federatsii i Pravitel'stvom Respubliki Kazakhstan o statuse korrespondentov sredstv massovoy informatsii Rossiyskoy Federatsiyey v Respublike Kazakhstan i korrespondentov sredstv massovoy informatsii Respubliki Kazakhstan v Rossiyskoy Federatsiyey. Ministerstvo inostrannykh del Rossiyskoy Federatsii. [Agreement between the Government of the Russian Federation and the Government of the Republic of Kazakhstan on the status of mass media reporters of the Russian Federation in the Republic of Kazakhstan, and of mass media reporters of the Republic of Kazakhstan in the Russian Federation. Ministry of Foreign Affairs of the Russian Federation], (2000). https://www.mid. ru/foreign_policy/international_contracts/2_contract/-/storage-viewer/bilateral/ page-215/46821 (Accessed 14.04.2020).

16. Radioveshchaniye v Rossii v 2017 godu. Otraslevoy doklad. [Radio-broadcasting in Russia in 2017. Industry report]. Federal Agency for Press and Mass Media, Moscow, (2018).

17. Radioveshchaniye v Rossii v 2018 godu. Otraslevoy doklad. [Radio-broadcasting in Russia in 2018. Industry report]. Federal Agency for Press and Mass Media, Moscow, (2019).

18. Kazakhstanskaya telekompaniya prekrashchayet retranslyatsiyu trekh rossiyskikh kanalov. [Kazakhstan TV company terminates broadcasting three Russian channels]. Vesti (2012). https://www.vesti.ru/doc.html?id=727144 (Accessed 16.04.2020).

19. Prekrashchayetsya retranslyatsiya chetyrekh rossiyskikh kanalov. [Broadcasting of four Russian channels is terminated]. Forbes (2017). https://forbes.kz// massmedia/prekraschaetsya_retranslyatsiya_chetyireh_rossiyskih_kanalov/ (Accessed 16.04.2020).

20. Televideniye v Rossii v 2019 godu. Otraslevoy doklad. [TV in Russia in 2019. Industry report]. Moscow: Federal Agency for Press and Mass Media, (2020).

21. Rossiya i Kazakhstan obsudili sotrudnichestvo v oblasti SMI. Ministerstvo tsifrovogo razvitiya, svyazi i massovykh kommunikatsiy Rossiyskoy Federatsii. [Russia and Kazakhstan discussed the media cooperation. Ministry of Digital Development, Communication and Mass Media of the Russian Federation], (2014). https://digital. gov.ru/ru/events/31950/ (Accessed 15.04.2020).

22. Voronezhskiy pisatel' nagrazhdon za razvitiye grazhdanskogo obshchestva $\mathrm{v}$ Kazakhstane. [A writer from Voronezh is awarded for the development of civil society in Kazakhstan. Commonwealth of Eurasian nations], (2015). http://evrazia-ural.ru/ novosti/voronezhskiy-pisatel-nagrazhdyon-za-razvitie-grazhdanskogo-obshchestvav-kazahstane (Accessed 29.06.2020). 
23. Dvustoronneye sotrudnichestvo s Respublikoy Kazakhstan. Ministerstvo tsifrovogo razvitiya, svyazi i massovykh kommunikatsiy Rossiyskoy Federatsii. [Bilateral cooperation with the Republic of Kazakhstan]. Ministry of Digital Development, Communication and Mass Media of the Russian Federation, (2018). https://digital. gov.ru/ru/activity/directions/687/ (Accessed 14.04.2020).

24. Rossiyskaya periodicheskaya pechat'. Sostoyaniye, tendentsii i perspektivy razvitiya. [Russian periodical press. Current state, trends and development perspectives]. Federal Agency for Press and Mass Media, Moscow, (2019).

25. Ekaterinburg sobral molodykh zhurnalistov iz stran YEAES i Tadzhikistana dlya obsuzhdeniya voprosov integratsii. [Yekaterinburg gathered young reporters from EEU countries and Tajikistan to discuss the issues of integration]. Ural-Eurasia, (2016). https://ural-eurasia.ru/component/content/article/19-specialprojects/schools/43-ekaterinburg-sobral-molodykh-zhurnalistov-iz-stran-eaesi-tadzhikistana-dlya-obsuzhdeniya-voprosov-integratsii? Itemid=101 (Accessed 26.08.2020).

26. Yevraziyskiye zhurnalisty poluchili novyye znaniya o Rossii. [Eurasian reporters gained new knowledge about Russia]. Ural-Eurasia, (2018). https://ural-eurasia.ru/component/content/article/19-special-projects/schools/479-evrazijskiezhurnalisty-poluchili-novye-znaniya-o-rossii? Itemid=101 (Accessed 29.06.2020).

27. Novyy vzglyad na staryye temy: kazakhstanskiye zhurnalisty obuchayutsya $\mathrm{v}$ mediashkole v Moskve. [New views of old issues: reporters from Kazakhstan attend media-school in Moscow]. Sputnik News, (2019). https://ru.sputniknews. kz/Russia/20190829/11389235/zhurnalisty-mediashkola-moskow.html (Accessed 29.06.2020).

28. Bez prikras o problemakh sovremennoy zhurnalistiki. [The problems of modern journalism straightaway]. Ural-Eurasia, (2018) https://ural-eurasia.ru/component/content/article/19-special-projects/schools/634-bez-prikras-o-problemakhsovremennoj-zhurnalistiki? Itemid=101 (Accessed 26.08.2020).

29. Kul'turno-gumanitarnoye sotrudnichestvo Kazakhstana i Rossii v 2019 godu. Posol'stvo Respubliki Kazakhstan v Rossiyskoy Federatsii. [Cultural and humanitarian cooperation of Kazakhstan and Russia in 2019. Embassy of the Republic of Kazakhstan in the Russian Federation]. https://www.kazembassy.ru/rus/ sotrudnichestvo/dvustoronnee_sotrudnichestvo/kulturno-gumanitarnoe_sotrud/ (Accessed 14.04.2020).

30. Internet v Rossii v 2019 godu. Otraslevoy doklad. [Internet in Russia in 2019. Industry report]. Moscow: Federal Agency for Press and Mass Media, (2020). 
31. Soglasheniye mezhdu Pravitel'stvom Rossiyskoy Federatsii i Pravitel'stvom Kirgizskoy Respubliki o sotrudnichestve v gumanitarnoy sfere. Elektronnyy fond pravovoy i normativno-tekhnicheskoy dokumentatsii. [Agreement between the Government of the Russian Federation and the Government of the Kyrgyz Republic on humanitarian cooperation. Electronic fund of legal and technical documentation], (2012). http://docs.cntd.ru/document/902343853 (Accessed 16.04.2020).

32. Soglasheniye mezhdu Pravitel'stvom Rossiiskoy Federacii i Pravitel'stvom Respubliki Kazakhstan o statuse korrespondentov sredstv massovoy informatsii Rossiiskoy Federacii v Respubliki Kazakhstan i korrespondentov sredstv massovoy informatsii Respubliki Kazakhstan v Rossiiskoy Federacii. Posol'stvo Rossiiskoy Federacii v Respubliki Kazakhstan. [Agreement between the Government of the Russian Federation and the Government of the Kyrgyz Republic on the status of mass media reporters of the Russian Federation in the Kyrgyz Republic and of mass media reporters of the Kyrgyz Republic in the Russian Federation]. Russian Embassy in Kyrgyzstan, (1995). https://kyrgyz.mid.ru/rossijsko-kirgizskie-otnosenia/-/asset_publisher/1VaUb5A3D8Sm/content/dogovorno-pravovaa-baza-rossijsko-kirgizskihotnosenij?inheritRedirect $=$ false $\&$ redirect $=$ https $\% 3 \mathrm{~A} \% 2 \mathrm{~F} \% 2 \mathrm{Fkyrgyz} \cdot \mathrm{mid} \cdot \mathrm{ru} \%$ 3A443\%2Frossijsko-kirgizskie-otnosenia\%3Fp_p_id\%3D101_INSTANCE_1VaUb5A3D8Sm\% 26p_p_lifecycle\%3D0 \%26p_p_state\%3Dnormal\%26p_p_mode\%3Dview\%26p_p_col_id\%3Dcolumn-1\%26p_p_col_count\%3D1 (Accessed 08.12.2019).

33. Soglasheniye mezhdu Pravitel'stvom Rossiyskoy Federatsii i Pravitel'stvom Kirgizskoy Respubliki o poryadke i usloviyakh rasprostraneniya programm rossiyskikh teleradioveshchatel'nykh organizatsiy na territorii Kirgizskoy Respubliki. [Agreement between the Government of the Russian Federation and the Government of the Kyrgyz Republic on the procedure and the conditions of the distribution of the programs of Russian television and radio broadcasting organizations in the territory of the Kyrgyz Republi]c. Conventions.ru, (1996). http://www.conventions. ru/view_base.php?id=15666 (Accessed 26.08.2020).

34. Soglasheniye mezhdu Pravitel'stvom Rossiyskoy Federatsii i Pravitel'stvom Kirgizskoy Respubliki o sotrudnichestve v oblasti informatsii. Elektronnyy fond pravovoy i normativno-tekhnicheskoy dokumentatsii. [Agreement between the Government of the Russian Federation and the Government of the Kyrgyz Republic on the cooperation in the area of information. Electronic fund of legal and technical documentation], (1999). http://docs.cntd.ru/document/901878296 (Accessed 05 April 2020).

35. Radio v Rossii v 2019 godu. Otraslevoy doklad. [Radio in Russia in 2019. Industry report]. Moscow: Federal Agency for Press and Mass Media, (2020). 
36. Mikhail Mamonov took part in the meeting of Russian-Kyrgyz intergovernmental commission. Ministry of Digital Development, Communication and Mass Media of the Russian Federation (2019). https://digital.gov.ru/ru/events/38814/ (Accessed 26 August 2020).

37. V Kirgizii prodlili retranslyaciu rossiiskih telekanalov. [Broadcasting of Russian channels is prolonged in Kyrgyzstan]. Krasnaya vesna, (2020). https://yandex. $\mathrm{ru} /$ turbo/s/rossaprimavera.ru/news/5ed72295?utm_source=yxnews\&utm_medium=desktop (Accessed 26 August 2020).

38. Rossiyskiye kanaly ostayutsya. [Russian channels stay]. Rossiyskaya Gazeta, (2015). https://rg.ru/2015/06/04/veshanie.html (Accessed 26 August 2020).

39. V.A. Soloviov. Formirovaniye yedinykh professional'nykh standartov v informatsionnom prostranstve stran SNG. [Formation of unified professional standards in the information space of the CIS countries]. Vestnik Moskovskogo gosudarstvennogo lingvisticheskogo universiteta. Gumanitarnyye nauki. [Journal of Moscow State Linguistic University. Humanitarian sciences]. Vol. 11 (2016). https://cyberleninka. $\mathrm{ru} /$ article/n/formirovanie-edinyh-professionalnyh-standartov-v-informatsionnomprostranstve-stran-sng-1 (Accessed 18 April 2020).

40. Minkomsvyaz' Rossii i Ministerstvo kul'tury, informatsii i turizma Kirgizii podpisali memorandum o sotrudnichestve. Ministerstvo tsifrovogo razvitiya, svyazi i massovykh kommunikatsiy Rossiyskoy Federatsii. [Ministry of communications of Russia and Ministry of culture, information and tourism of Kyrgyzstan signed a memorandum on cooperation. Ministry of Digital Development, Communication and Mass Media of the Russian Federation], (2015). https://digital.gov.ru/ru/ events/33327/ (Accessed 15 April 2020).

41. Dvustoronneye sotrudnichestvo s Kyrgyzskoy Respublikoy. Ministerstvo tsifrovogo razvitiya, svyazi i massovykh kommunikatsiy Rossiyskoy Federatsii. [Bilateral cooperation with the Kyrgyz Republic. Ministry of Digital Development, Communication and Mass Media of the Russian Federation], (2018). https://digital. gov.ru/ru/activity/directions/627/\#section-events (Accessed 15 April 2020).

42. Soglasheniye mezhdu Pravitel'stvom Rossiyskoy Federatsii i Pravitel'stvom Respubliki Tadzhikistan o sotrudnichestve v oblasti kul'tury, nauki i tekhniki, obrazovaniya, zdravookhraneniya, informatsii, sporta i turizma. Elektronnyy fond pravovoy i normativno-tekhnicheskoy dokumentatsii. [Agreement between the Government of the Russian Federation and the Government of the Republic of Tajikistan on the cooperation in the areas of culture, science and technology, education, healthcare, information, sport and tourism. Electronic fund of legal and technical documentation], (1995). http://docs.cntd.ru/document/1901169 (Accessed 06 April 2020). 
43. Soglasheniye mezhdu Pravitel'stvom Rossiyskoy Federatsii i Pravitel'stvom Respubliki Tadzhikistan o sotrudnichestve v oblasti informatsii. Elektronnyy fond pravovoy i normativno-tekhnicheskoy dokumentatsii. [Agreement between the Government of the Russian Federation and the Government of the Republic of Tajikistan on the cooperation in the area of information. Electronic fund of legal and technical documentation], (2004). http://docs.cntd.ru/document/901915132 (Accessed 26 August 2020).

44. Soglasheniye mezhdu Pravitel'stvom Rossiyskoy Federatsii i Pravitel'stvom Respubliki Tadzhikistan o statuse korrespondentov sredstv massovoy informatsii Rossiyskoy Federatsii v Respublike Tadzhikistan i korrespondentov sredstv massovoy informatsii Respubliki Tadzhikistan v Rossiyskoy Federatsii. Elektronnyy fond pravovoy i normativno-tekhnicheskoy dokumentatsii. [Agreement between the Government of the Russian Federation and the Government of the Republic of Tajikistan on the status of mass media reporters of the Russian Federation in the Republic of Tajikistan and mass media reporters of the Republic of Tajikistan in the Russian Federation. Electronic fund of legal and technical documentation], (2001). http://docs.cntd.ru/document/901830357 (Accessed 06 April 2020).

45. Soglasheniye mezhdu Pravitel'stvom Rossiyskoy Federatsii i Pravitel'stvom Respubliki Tadzhikistan o poryadke i usloviyakh priyema i rasprostraneniya programm rossiyskikh teleradioveshchatel'nykh organizatsiy na territorii Respubliki Tadzhikistan. Elektronnyy fond pravovoy i normativno-tekhnicheskoy dokumentatsii. [Agreement between the Government of the Russian Federation and the Government of the Republic of Tajikistan on the procedure and the conditions of the distribution of the programs of Russian TV and radio broadcasting organizations in the territory of the Republic of Tajikistan. Electronic fund of legal and technical documentation], (1999). http://docs.cntd.ru/document/1000001147 (Accessed 26 August 2020).

46. V Rossii otkrylsya korpunkt tadzhikskogo gosudarstvennogo kanala «Dzhakhonnamo». [News bureau of Tajik state channel "Jahonnamo" opened in Russia]. Commonwealth of Eurasian nations, (2017). http://evrazia-ural.ru/novosti/vrossii-otkrylsya-korpunkt-tadzhikskogo-gosudarstvennogo-kanala-dzhahonnamo (Accessed 26 August 2020).

47. Mediapredpochteniya naseleniya Respubliki Tadzhikistan: TV, radio, pechatnyye izdaniya, sayty, sotsial'nyye seti i messendzhery. [Media preferences of the population of the Republic of Tajikistan: TV, radio, mass media, web-sites, social networks and messengers]. Zerkalo Centre for sociological research. http://zerkalo. tj/uploads/files/2020/MediaPreff-2019_Final_RUS.pdf (Accessed 17 April 2020). 
48. Soglasheniye mezhdu Pravitel'stvom RF i Pravitel'stvom RUz o sotrudnichestve v oblasti kul'tury, nauki i tekhniki, obrazovaniya, zdravookhraneniya, informatsii, sporta i turizma. Elektronnyy fond pravovoy i normativno-tekhnicheskoy dokumentatsii. [Agreement between the Government of the Russian Federation and the Government of the Republic of Uzbekistan on the cooperation in the areas of culture, science and technology, education, healthcare, information, sport and tourism. Electronic fund of legal and technical documentation], (1993). http://docs. cntd.ru/document/1902102 (Accessed 26 August 2020).

49. Soglasheniye mezhdu Pravitel'stvom Rossiiskoy Federacii i Pravitel'stvom Respubliki Uzbekistan o statuse korrespondentov SMI Rossiiskoy Federacii v Respubliki Uzbekistan i korrespondentov SMI Respubliki Uzbekistan v Rossiiskoy Federacii. Elektronnyy fond pravovoy i normativno-tekhnicheskoy dokumentatsii. [Agreement between the Government of the Russian Federation and the Government of the Republic of Uzbekistan on the status of Russian reporters in the Republic of Uzbekistan and Uzbek reporters in the Russian Federation. Electronic fund of legal and technical documentation], (1998). http://docs.cntd.ru/document/8318287 (Accessed 17 April 2020).

50. Soglasheniye mezhdu Pravitel'stvom Rossiiskoy Federacii i Pravitel'stvom Respubliki Uzbekistan o sotrudnichestve v oblasti informatsii. Elektronnyy fond pravovoy i normativno-tekhnicheskoy dokumentatsii. [Agreement between the Government of the Russian Federation and the Government of the Republic of Uzbekistan on the cooperation in the area of information. Electronic fund of legal and technical documentation], (1999). http://docs.cntd.ru/document/901753166 (Accessed 26 August 2020).

51. N. Koshkin. Uzbekistantsy po-prezhnemu predpochitayut rossiyskoye televideniye mestnomu. [Uzbek citizens still prefer Russian TV to the local one]. Fergana News, (2003). https://www.fergananews.com/articles/2374 (Accessed 26 August 2020).

52. V stolitse Uzbekistana nablyudayetsya bum prodazh sputnikovykh antenn. [Sales of satellite aerials in the capital of Uzbekistan are booming]. Fergana News, (2011). https://www.fergananews.com/articles/6910 (Accessed 26 August 2020).

53. Uzbekistan: Telekanal «Domashniy» zakryli iz-za turetskogo seriala ili iz-za russkogo yumora? [Uzbekistan: "Domashny" channel closed because of a Turkish TV series or because of Russian humor?]. Fergana News, (2013). https://www.fergananews.com/articles/7843 (Accessed 17 April 2020).

54. Dvustoronneye sotrudnichestvo s Respublikoy Uzbekistan. Ministerstvo tsifrovogo razvitiya, svyazi i massovykh kommunikatsiy Rossiyskoy Federatsii. [Bilat- 
eral cooperation with the Republic of Uzbekistan. Ministry of Digital Development, Communication and Mass Media of the Russian Federation], (2018). https://digital. gov.ru/ru/activity/directions/558/ (Accessed 17 April 2020).

55. V Minkomsvyazi obsudili rossiysko-uzbekskoye sotrudnichestvo v sfere infomacii I kommunicacii. Ministerstvo tsifrovogo razvitiya, svyazi i massovykh kommunikatsiy Rossiyskoy Federatsii. [The Ministry of communications discussed Russian-Uzbek cooperation in the areas of information and communications. Ministry of Digital Development, Communication and Mass Media of the Russian Federation], (2019). https://digital.gov.ru/ru/events/38822/ (Accessed 17.04.2020).

56. V Tashkente prokhodit pervyy uzbeksko-rossiyskiy mediaforum. [First Uzbek-Russian Media Forum is held in Tashkent]. Sputnik Tajikistan, (2018). https:// tj.sputniknews.ru/asia/20181006/1027026535/tashkente-prohodit-pervyy-uzbekskorossiyskiy-mediaforum.html (Accessed 17 April 2020).

57. Postoyannyy neytralitet Turkmenistana. Rezolyutsiya General'noy Assamblei Organizatsii Ob"yedinennykh Natsiy. Elektronnyy fond pravovoy i normativnotekhnicheskoy dokumentatsii. [Continuous neutrality of Turkmenistan. Resolution of the United Nations General Assembly. Electronic fund of legal and technical documentation], (1995). http://docs.cntd.ru/document/901739070 (Accessed 15 April 2020).

58. Agreement between the Government of the Russian Federation and the Government of Turkmenistan on the status of Russian reporters in Turkmenistan and Turkmen reporters in Russia. Conventions.ru (1995). http://www.conventions. ru/view_base.php?id=15152 (Accessed 26 August 2020).

59. Turkmenskiy paradoks: russkogo yazyka de-yure net, de-fakto on neobkhodim. [Turkmen Paradox: de jure, there is no Russian language, de facto, it is necessary]. Central Asian Bureau for Analytical Reporting CABAR.asia, (2019). https://cabar.asia/ru/turkmenskij-paradoks-russkogo-yazyka-de-yure-net-de-faktoon-neobhodim/ (Accessed 15 March 2020).

60. Dogovor mezhdu Rossiyskoy Federatsiyey i Turkmenistanom o strategicheskom partnerstve. Elektronnyy fond pravovoy i normativno-tekhnicheskoy dokumentatsii. [The Treaty on the strategic partnership between the Russian Federation and Turkmenistan. Electronic fund for legal and technical documentation], (2017). http://docs.cntd.ru/document/456098103 (Accessed 03 April 2020). 